\title{
UNA TERRACOTA CON REPRESENTACIÓN ANÚBICA PROCEDENTE DE GADES
}

\section{A TERRACOTTA WITH ANUBIC REPRESENTATION FROM GADES}

\section{Macarena BUSTAMANTE ÁLVAREZ ${ }^{1 *}$, Ma Eugenia GARCÍA PANTOJA ${ }^{2 * *}$, Jónatan ORTIZ GARCÍA ${ }^{3 * * *}$ y Sandra MARTÍN MARTÍNEZ ${ }^{4 * * * *}$}

${ }^{1}$ Universidad de Granada, Uniarq - Lisboa

${ }^{2}$ Junta de Andalucía

${ }^{3}$ Contratado postdoctoral Juan de la Cierva - Formación, Departamento de Historia y Filosofía, Universidad de Alcalá, Alcalá de Henares, Madrid

${ }^{4}$ Universidad de Granada

* Correo electrónico: mbustamante@ugr.es

** Correo electrónico: eugarciapantoja@gpme-arqueologia.com

*** Correo electrónico: jonatan.ortiz@uah.es

**** Correo electrónico: sandramm96@ugr.es

Resumen: Se presenta un análisis contextual, iconográfico y funcional de una terracota hallada en una excavación arqueológica desarrollada en el solar de la antigua Gades. Iconográficamente, se asocia al culto funerario en el extremo occidental del Mediterráneo y, posiblemente, fue manufacturada en unos alfares foráneos a Gades. El interés de este estudio radica, por un lado, al ser la primera vez que este tipo de piezas aparece en Hispania y, por otro, por aparecer contextualizada, hecho que nos permite lanzar hipótesis más concretas sobre su hallazgo.

Palabras Clave: Gades, terracota, Egipto, Anubis, Arqueología urbana.

\begin{abstract}
A contextual, iconographic, and functional analysis of a terracotta found in an archaeological excavation carried out on the ancient site of Gades is presented. Iconographically, it is associated with the funerary cult at the western end of the Mediterranean and, possibly, it was manufactured in foreign kilns to Gades. The interest of this study lies, on the one hand, as it is the first time that this type of piece appears in Hispania and, on the other, because it appears contextualized. This fact allows us to develop more concrete hypotheses about its finding.
\end{abstract}

Keywords: Gades, terracotta, Egypt, Anubis, urban Archaeology.

Sumario: 1. Introducción. 2. Datos sobre el hallazgo. La intervención en la c/Teniente Andújar. 3. Una terracota singular con representación egiptizante. 4. Aspectos conclusivos. 5. Bibliografía.

\section{Introducción}

La proliferación de los cultos orientales no es un hecho aislado, ni puntual, todo lo contrario es un fenómeno consabido y bien estudiado para el extremo occidental del Mediterráneo. Quizás uno de los primeros que reflexionaron sobre este fenómeno en el Círculo del Estrecho fue A. Sáez (1979), el homenajeado en el presente volumen. Este investigador, a partir de un singular hallazgo acaecido en Barbate, consistente en un ara con símbolos variados - prótomo de toro, estrellas, serpientes o elementos fitomorfos-, apuntó a la posible asociación de esta pieza a un templo dedicado al dios iranio Mitra en el entorno de Baesippo (actual Barbate). Esta línea de trabajo, aunque no fue continuada, supuso la cimentación de una prolífera y dilatada vida científica.

Nuestra aportación a este volumen recoge, en cierta medida, el "guante" lanzado en esa publicación, los cultos orientales en el extremo mediterráneo. En concreto, presentamos un ejemplar de figura egiptizante, de cronología altoimperial, hecha en terracota y localizada en una intervención 
arqueológica desarrollada en 2005 en la c/Teniente Andújar, sita en el casco antiguo del actual Cádiz (Figura 1). En las siguientes páginas efectuaremos un análisis integral de la misma en la que, además de una descripción morfológica y funcional, se evalúa su simbolismo y significación en este espacio. Aprovechamos, también la ocasión para aportar otros ejemplos sobre representaciones similares de época romana en esta zona geográfica que nos permita aportar una significación completa de este interesante fenómeno.

\section{Datos sobre el hallazgo. La intervención en la c/Teniente Andújar}

El solar donde se localizó esta pieza, se ubica en pleno Barrio de Santa María, una de las zonas más altas desde el punto de vista topográfico de la ciudad lo que le imprime al lugar una importancia geoestratégica añadida. De hecho, en sus inmediaciones, en la denominada como Huerta del Hoyo, se ha venido ubicando el posible anfiteatro de épo- ca romana a raíz de los datos que arroja la cartografía del XVII.

Además, en las inmediaciones se han ido sucediendo los hallazgos que apuntan a una intensa ocupación en época altoimperial como en la c/San Roque, Mirador 18-19, 21 y 27, Viento 2-4, Merced 3-5 y 11, Botica 26, 31 y 33, Santa Elena 4, Sopranis 29, San Juan de Dios 8, San Juan Bautista 12, Troilo 5, Suárez de Salazar o Plaza de la Merced 16, 18 ó 20 , o Jabonería entre otros. En todos ellos se pone de relieve que la fase romana, claramente, se aleja de la función funeraria que este espacio tuvo en épocas precedentes, desplegándose en este momento una prolífera ocupación de tipo urbano, habitacional o artesanal como se constata por la continua presencia de pavimentos en opus signinum.

Esta excavación se inició en el año 2005 y comprendió una primera actuación centrada en la exhumación de los pavimentos y cimentaciones contemporáneas así como la delimitación de un gran aljibe de época moderna. Ante esto se diseñó un plan de actuación centrado en dos sondeos 1 ( 3 x 3,70 m.) y
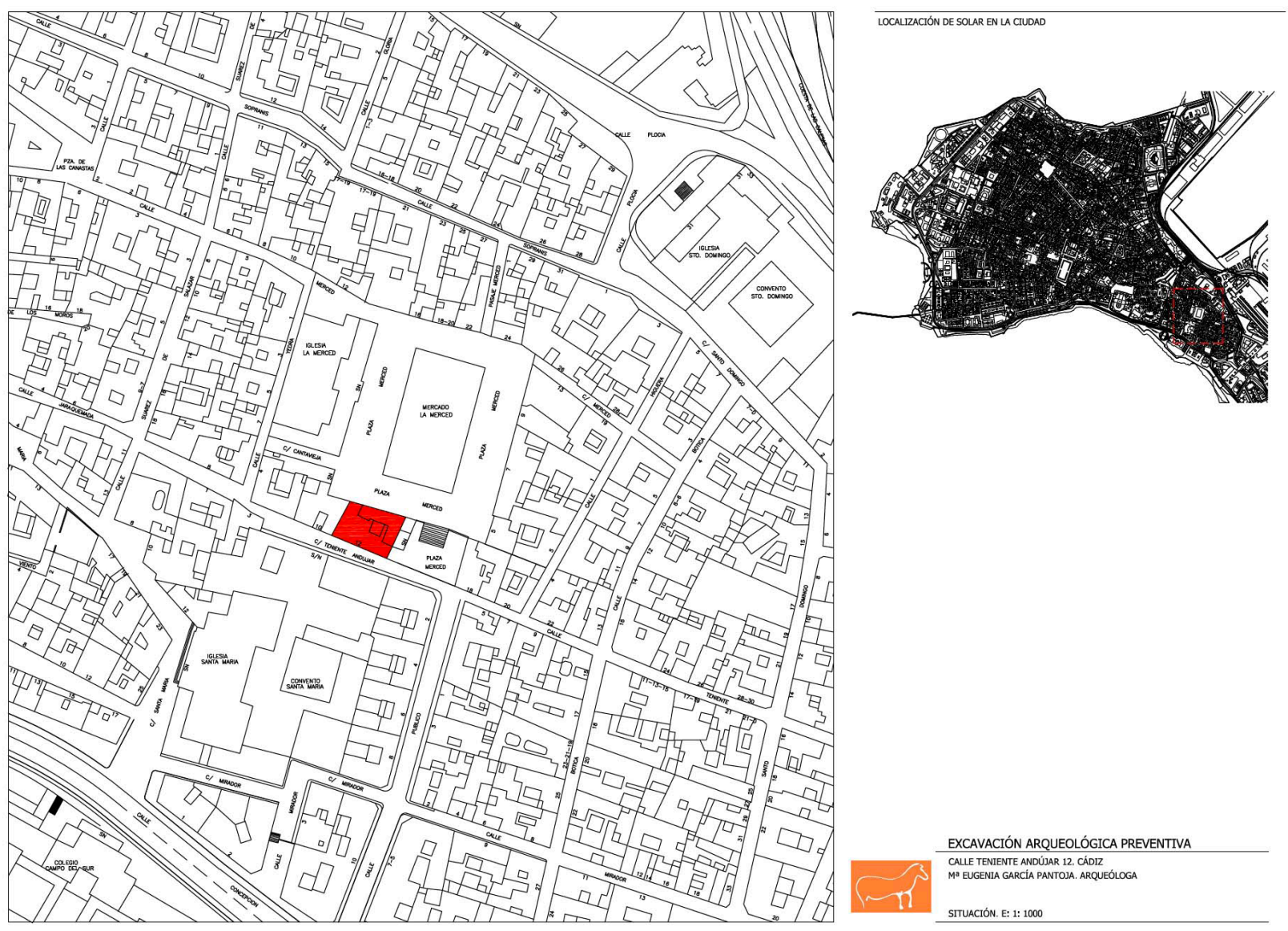

Figura 1. Ubicación del solar en el entramado urbano del actual Cádiz. (Fuente: cortesía D.E.A.). 
2 (4 x $3 \mathrm{~m}$.) que terminaron por ampliarse en extensión debido a la entidad de las estructuras.

A continuación abordaremos de manera muy sucinta los resultados de la intervención por facies cronológicas hasta llegar a época romana momento que centra este estudio y donde la descripción será más prolífera:

- Horizonte contemporáneo: se localizaron los restos de una casa palaciega (vivienda) del XIX acompañada por un imponente aljibe que, en algunos puntos, llegaba hasta el geológico. Esta subestructura terminó por obliterar restos de épocas previas.

- Fase moderna: donde se ha podido aislar hasta tres momentos. Un primero, muy arrasado donde se atisba una pileta de funcionalidad incierta. Un segundo, con estructuras a distinto nivel que podrían haber formado parte de un muro de contención o aterrazamiento y, un último nivel, el más profundo formado por paquetes de aporte posiblemente para nivelar el terreno.

Sin embargo, la época que nos centra, la romana, ha aportado datos de interés para conocer la ocupación del Gades romano en la zona que nos ocupa. En ambos sondeos se observó la presencia de importantes muros de época romana altoimperial (ca. entre 40-60 cm. de anchura) en los que se implementa el opus incertum y un pseudovitattum a partir de conglomerado conchífero trabado con arcilla y enlucido con cal blanca. En algunos puntos, estas estructuras alcanzaban los $98 \mathrm{~cm}$. de alto de lo que se extrapola el buen estado de conservación en el que se encuentran.

En este solar se constriñe un edificio delimitado al Oeste a partir de un largo muro (más de 12 m.), el UE. 17 que flanquea el espacio por su flanco NE y actuaría de cierre de este edificio. Además, presenta la base de una columna de unos $1.40 \mathrm{~m}$. En este espacio delimitado se desarrollan tanto habitaciones como un gran patio diáfano en el que no se ha podido individualizar ninguna estructura. Entre este muro que actúa de cierre del edificio y las estructuras que a continuación vamos a describir, se encontraría un pasillo que permitiría el tránsito al interior del edificio.

En relación a las estancias, se ha podido aislar hasta 4 ámbitos (Figura 2):

- Habitación 1: delimitada por los muros UU.CC. 37 (Este) y 38 (Sur) (Figura 3). Aún se conserva la jamba de acceso así como su pavimento. Este último plantea una dualidad; por un lado presenta tegulae posicionadas cara-abajo (UE. 48) y por otro también restos de caementicium (UE. 51). Este suelo estaba delimitado por dos líneas de ladrillos verticales que permiten lanzar la hipótesis de que estamos ante dos piletas improvisadas. La falta de recubrimiento hidrófugo en las paredes pueden diluir la idea de una funcionalidad para contener líquidos, sin embargo, esta compartimentación tuvo una función clara de división de los allí contenido. Este espacio estaba colmatado por varias ánforas, entre las que se destaca una Dr. 20 completa.

- Habitación 2: delimitada por las estructuras UU.CC. 37 (al Oeste), 38 (al Sur) y 56 (al Este). No se localizó la pavimentación de la misma.

- Habitación 3: constreñida por los muros UC. 56 (al Este), 57 (al Oeste) y 60 (al Sur). El suelo estaba manufacturado en opus caementicium. Dentro de este ámbito se pudo delimitar un pozo (UE. 58).

- Habitación 4: delimitada por las estructuras UU.CC. 56 (Este), 60 (al Norte) y 38 (al Sur). Presenta suelo de opus caementicium, sin embargo, todo este espacio estaba tremendamente afectado por la construcción del aljibe moderno.

En relación a la funcionalidad del espacio es difícil llevar a cabo una adscripción certera teniendo presente la escasa extensión intervenida. A pesar de ello, el monumental muro de cierre al que se le une la cimentación de una basa imponente de 1.40 m. de diámetro nos hablaría de una estructura posiblemente pública. A ello hay que añadirle cómo, a 3,80 m. aparece otro muro paralelo (UE. 63). Entre ambos se formaría así un espacio que podría haber hecho las veces de vial o lugar de tránsito interno dentro de esta construcción. Aunque no podemos indicar con exactitud qué tipo de edificio es el que hemos documentado, consideramos que estamos ante una construcción con un posible uso comercial, que se vincula con otros hallazgos del entorno como los localizados en la C/Suárez de la Salazar y sobre todo con los restos monumentales de la c/Jabonería. Este conjunto de edificios nos indica la presencia de un núcleo administrativo/ comercial vinculado con el Gades de los Balbo, aunque su uso fue relativamente limitado en el 


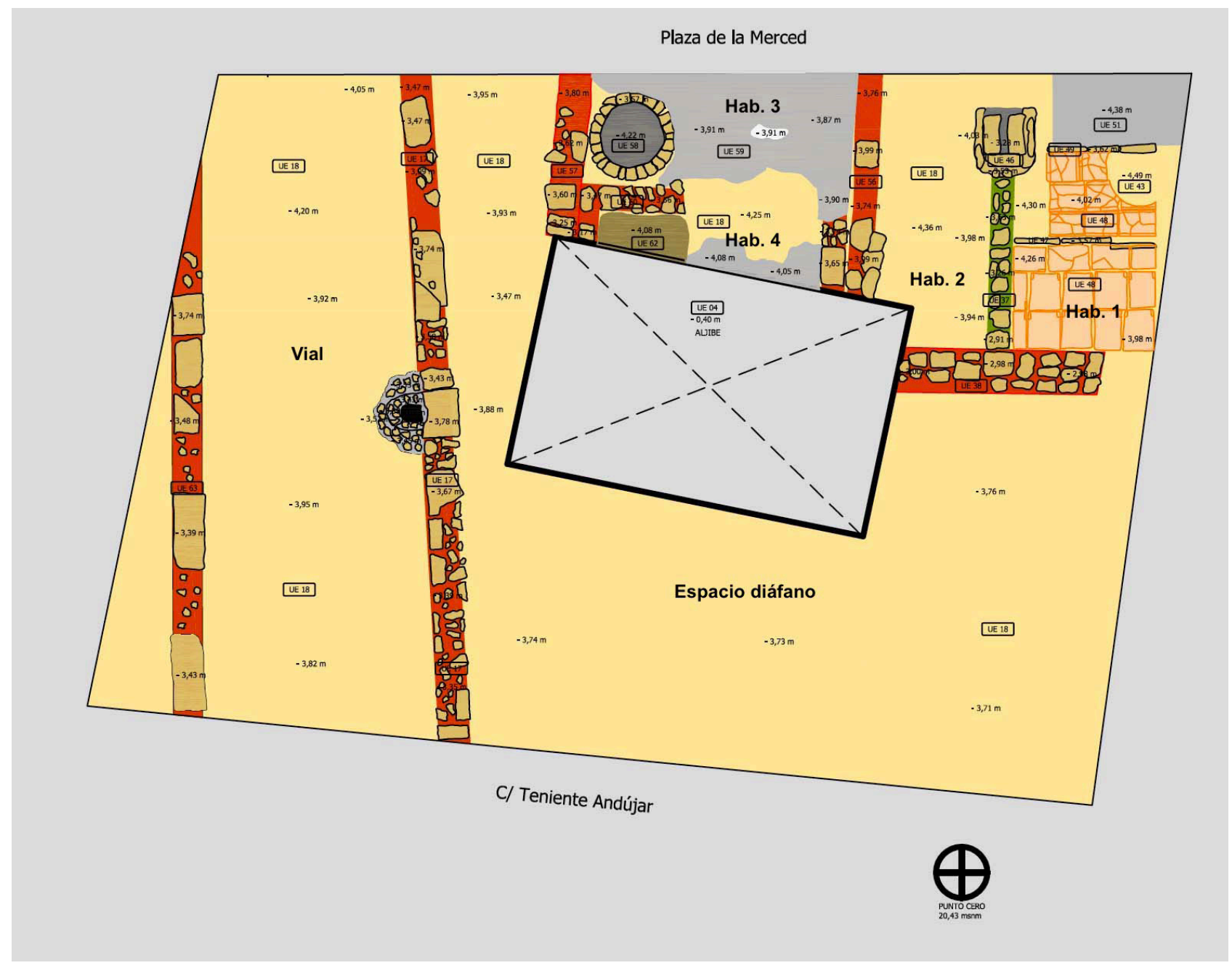

Figura 2. Planta con las estructuras romanas romanas localizadas. (Fuente: cortesía D.E.A.).

tiempo, ya que los niveles de abandono se sitúan avanzados en el siglo II d.C.

La cronología del final de este espacio se concluye por la presencia de una gran fosa excavada (UE. 61) entre el aljibe y el muro UE. 60. Esta fosa estaba rellena por dos estratos, el más profundo, la UE. 62 y el más superficial la UE. 36. De ambas UU.EE. la que más nos interesa es la UE. 36 que es el contexto en el que aparece la figura que pasamos a comentar. Esta unidad se conforma como un estrato con una potencia de más de 1,30 m. de arenas de coloración anaranjadas y muy suelta.

En relación a la cronología de este contexto viene aportada por un conjunto monetal de doce piezas que nos aportan una interesante cronología cuya pieza más moderna se ubica en la primera mitad del II d.C. (El estudio numismático fue desarrollado por D. J.M. López Eliso en el marco de la memoria final de la excavación).

- Cuadrante de Claudio (RIC I, 126, n1 84,
86-88 y 90) con anverso frusto y, probable leyenda circular interna [TI CLAVDIVS CAESAR AVG]. Reverso también frusto. Datada entre el 41-42 d.C.

- Cuadrante de Claudio (RIC I, 121, no 1) con anverso con cabeza ladeada de Claudio y leyenda circular interna [TI CLAVDIVS CAESAR AVG P M TR P IMP]. En el reverso alzado del altar de Lugdunum (Lyon) con corona cívica y laureles. Aparece flanqueado por Victorias sobre columnas. En el exergo aparece la leyenda [RO]M ET AVG. Datación propuesta del 41 d.C.

- Cuadrante de Claudio (RIC I, 126, no 84, 8688 y 90) con anverso con representación de modio con leyenda circular interna [TI CLAVDIVS CAESAR AVG]. En el reverso leyenda imprecisa. Cronología propuesta entre el 41-42 d.C.

- Dos Ases de Claudio (RIC I, 128, no 100) con 


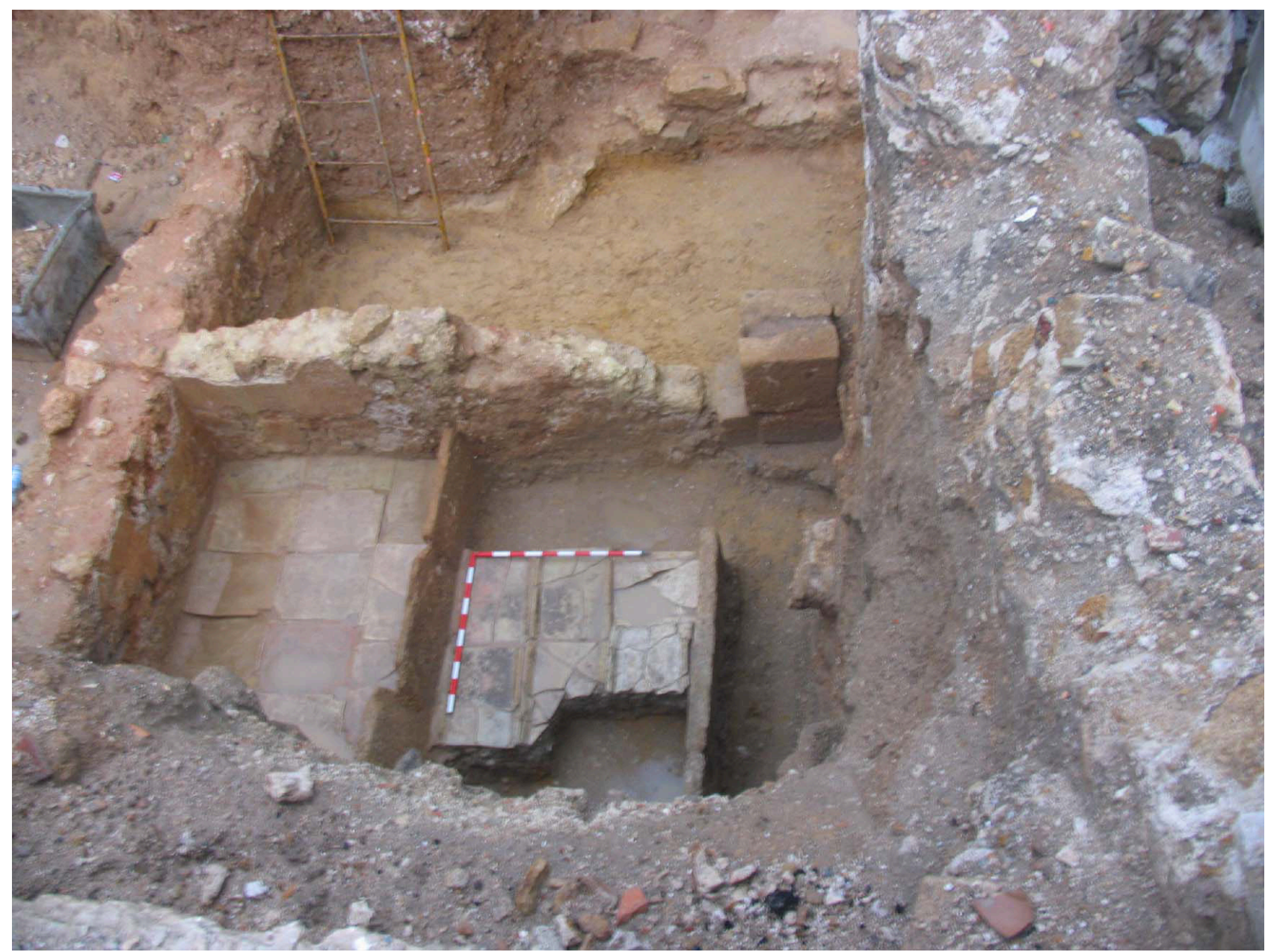

Figura 3. Imagen de las estructuras romanas localizadas. (Fuente: cortesía D.E.A.).

anverso con cabeza de Claudio a la izquierda y leyenda interna circular circular interna TI CLAVDIVS CAESAR AVG [P M TR P IMP]. En el anverso Minerva con casco y drapeada que arroja un pilum con su mano derecha y porta un scutum redondo sobre el brazo izquierdo con inscripción a ambos lados de SC. La datación propuesta es del 41-50 d.C.

- As de Domiciano (RIC II, 185, № 248 ó 188, no 270) con busto laureado de Domiciano a derecha con égida y leyenda circular interna IMP CAES DOMITIAN AVG GERM C[OS X] o IMP CAES DOMITIAN AVG GERM C[OS XI] en su anverso. En el reverso moneta en pie a izquierda portando balanza y cornucopia, leyenda circular interna [MONETA] AVGVST; a ambos lados de la figura [S.]C. La datación propuesta es 84-85 d.C.

- As de Adriano (inclasificable). Representación de Adriano con leyenda circular interna [HADRI]ANVS [AVGVSTVS]. En el anverso, figura femenina sedente. Cronología propues- ta $117-138$ d.C.

- 5 monedas frustras u obliteradas.

A pesar de que el conjunto parece apuntar a una cronología de la primera mitad del II d.C. la UE. 62, que se encuentra estratigráficamente en un nivel inferior, presenta otras piezas monetales que permiten delimitar esta interfaz en un terminus post-quem del 176-177 d.C. Entre las piezas se encontrarían:

- Sestercio de Adriano (RIC II, 423, no 634 o 424, no 635). En el anverso aparece el busto de Adriano, laureado con ropaje sobre el hombro izquierdo. En el reverso aparece Neptuno en pie a la izquierda, con el pie derecho sobre proa, manto sobre el muslo derecho, portando delfín y tridente o acrostolio en lugar de delfín. Presenta la leyenda circular interna [COS III] S.C. La datación aportada es 125-128 d.C.

- As de Adriano (inclasificable) con cabeza de Adriano en el anverso y figura femenina de pie en el reverso. La cronología de la pieza es 117-138 d.C. 
- As de Faustina (inclasificable). En su anverso representación de busto drapeado y peinado de recogido ondulado, además aparece la leyenda circular interna DIVA FAV[S] TINA. La cronología propuesta se centran en el post 141 d.C.

- Sestercio de Faustina (RIC III, 165, 1146) (Figura 4a). En el anverso aparece Faustina con busto drapeado y pelo ondulado y recogido, se acompaña de la leyenda interna DIVA AVGVSTA FAVSTINA. En el reverso pietas en pie a izquierda, arrojando incienso sobre un candelabro o altar y portando una caja de perfumes; se acompaña por la leyenda circular interna PIETAS AVG y a ambos lados de la figura S.C. La cronología que se le ha asociado es la de post 141 d.C.

- As de Marco Aurelio (RIC III, 308, no 1202)
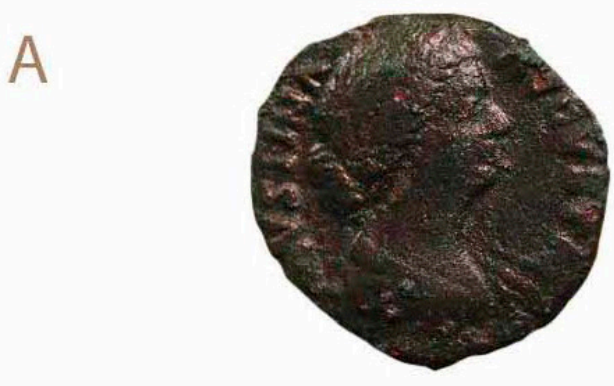

\section{B}
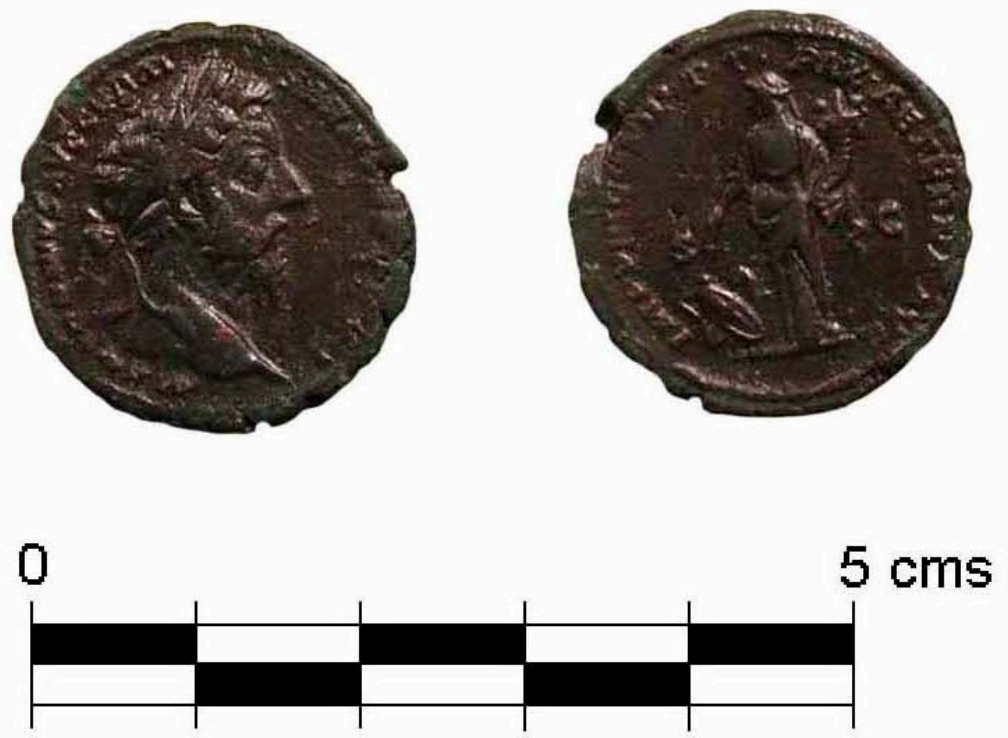

Figura 4. a) As de Faustina II (Fuente: RIC III, 347, 1680).

b) As de Marco Aurelio (Fuente: RIC III, 308, no 1202).

Revista Atlántica-Mediterránea de Prehistoria y Arqueología Social 22, pp. 209-227
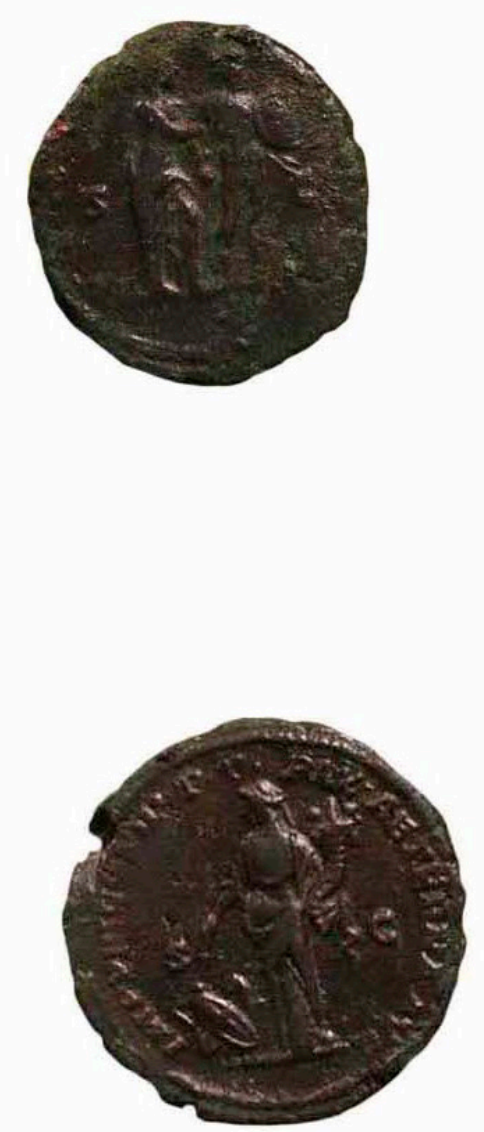

(Figura 4b). Con representación de Marco Aurelio a la derecha con leyenda circular interna M ANTONINVS AVG GERM SARM TR P XXXI. En el reverso, representación de personificación de Pax en pie con cornucopia y prendiendo fuego a un conjunto de armas. Además aparece la leyenda circular interna IMP VIII COS III P P PAX AETERNA AVG y a ambos lados de la figura S.C. La cronología propuesta es 176-177 d.C.

- As de Faustina II (RIC III, 347, 1680). Representación de Faustina II a la derecha con leyenda circular interna [F]AVSTINA AVGVSTA. En el reverso Venus, medio desnuda, en pie, agarrando el brazo de Marte en pie frontal, con la cabeza a izquierda y scutum. Se acompaña con la leyenda circular interna VENE[RI VICTRICI]. A ambos lados de las fi-

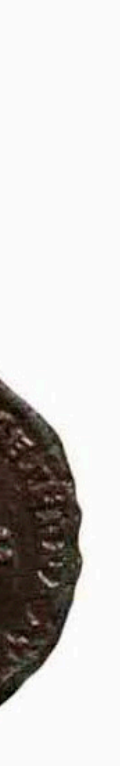

$5 \mathrm{cms}$

Universidad de Cádiz 
guras aparece la inscripción S.C. La datación que aporta es 161-175 d.C.

De igual modo la cronología se apuntala por la presencia de un broche de disco broncíneo de unos $2.70 \mathrm{~cm}$. de diámetro conformado por tres bandas concéntricas con esmaltado polícromo y botón central (Figura 5). Las placas de esmaltado se configuran cuadrangulares y se alternan de manera bícroma de la siguiente manera: banda más externa azul y blanco; blanda siguiente rojo y blanco y banda central blanco y color impreciso. El botón central presenta coloración verde, posiblemente, por la oxidación del metal. Este tipo de decoración concéntrica se ubica en la técnica millefiori G-H definida por Riha (1979, fig. 12).

En relación a su funcionalidad claramente nos encontramos ante una fibula que ha perdido todos los aderezos traseros que permitirían agarrarse a una prenda. A pesar de ello, se podría ubicar tipológicamente en el tipo Riha 7.14 datado entre la segunda mitad del II e inicios del III d.C.

Con todo lo aportado podemos precisar que la terracota que centra nuestro análisis se ubica en un estrato de amortización de un edificio conformado por varias estancias así como una parte diáfana. De interés radica la presencia de un posible vial que nos indica, claramente, que estamos ante un edificio inserto en la trama urbana de Gades como se desprende de la presencia de una calle así como una basa de columna. El hecho de que estemos ante una intervención urbana constriñe grandemente el espacio a los límites del solar y, por consiguiente, la interpretación de este lugar. A pesar de ello la presencia de un suelo de tegulae con algunos ladrillos hincados verticalmente, claramente, imprimen al espacio cierto componente comercial y/o artesanal.

\section{Una terracota singular con representación egiptizante}

La figura en cuestión está hecha en cerámica con una arcilla poco depurada como se extrae de los desgrasantes calcáreos de granulometría media-baja. Su coloración es anaranjada clara (Cailleux N-40). La pieza está fragmentada en tres que unen entre ellas (Figura 6).

A pesar de la fragmentación, podemos indicar que la pieza tendría aproximadamente unos 18 $\mathrm{cm}$. de largo y un ancho variable en función de la parte en la que nos centremos. En el caso del torso se podría alcanzar los $4 \mathrm{~cm}$. mientras que en la
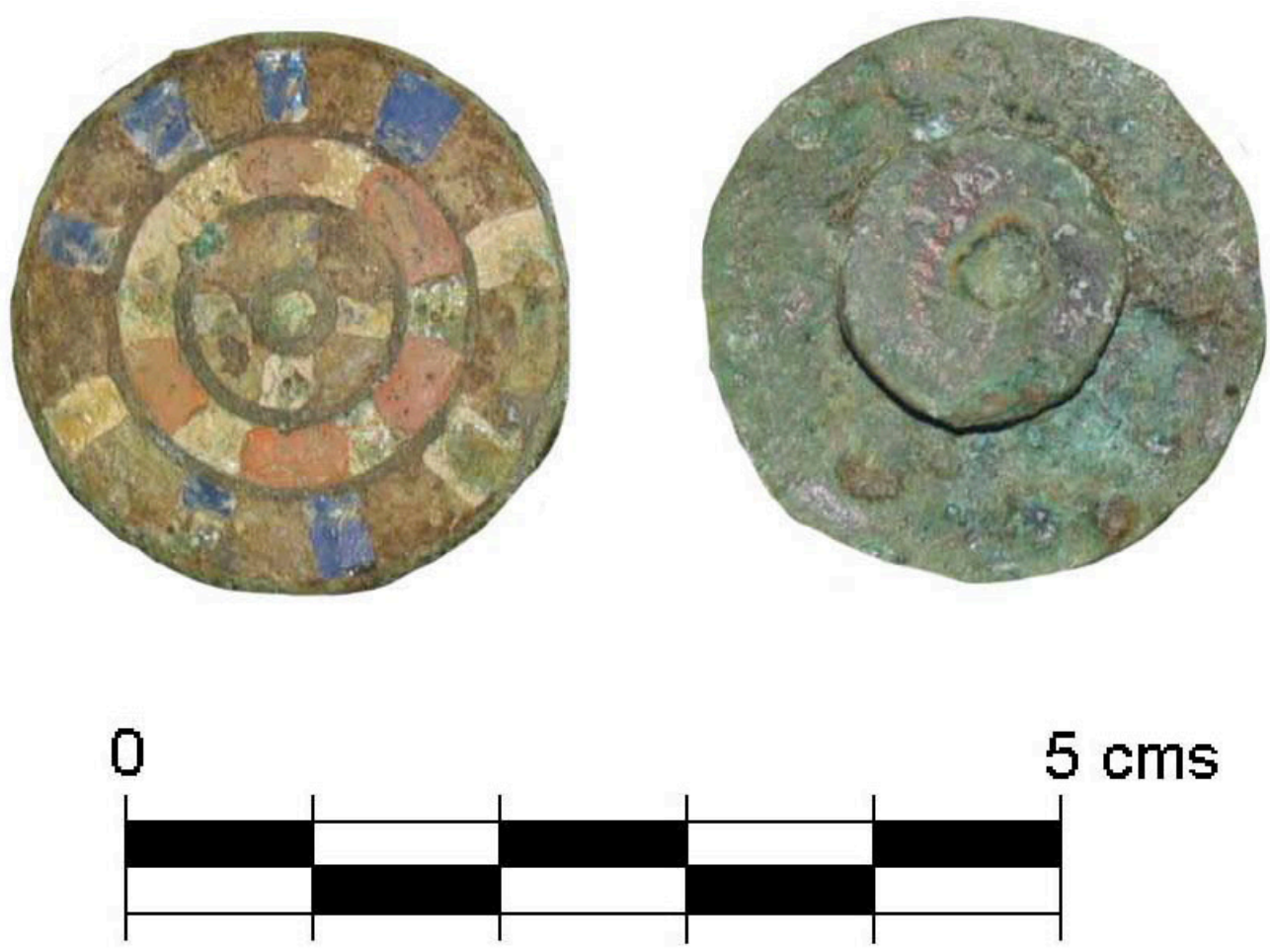

Figura 5. Broche romano hallado en la intervención. (Fuente: cortesía D.E.A.). 
cabeza o en los tobillos se llega escasamente a 3 $\mathrm{cm}$. La valva localizada alcanza hasta el $1,8 \mathrm{~cm}$. de grosor en algunos puntos y presenta impronta de las huellas dactilares del alfarero en cuestión.

Creemos que la pieza está hecha en un molde bivalvo aunque, únicamente, contamos con la parte delantera de la representación. A ello hay que sumarle que el punto donde se unirían ambas valvas está roto por lo que no podemos determinar cómo sería su unión.

Debido a la débil impresión de los detalles de la representación creemos que estamos ante un molde muy desgastado por el uso. Además del molde, se usó una lama de madera o metálica para la definición de la parte inferior de la peana estando aún la pieza fresca.

La terracota presenta una iconografía inusual pero identificable a pesar de la erosión que ha sufrido (Figura 6). Se observa una figura antropomorfa de pie y estática, que presenta prótomo de cánido con orejas erguidas entre las cuales hay un tocado compuesto por un elemento semicircular coronado por un disco encima. El personaje se encuentra envuelto con un manto cuyos extremos caen por el centro y terminan en flecos en la parte inferior, dejando las piernas de la figura visibles, sin que sea posible determinar si porta sandalias en unos pies no representados de forma muy realista. Los pliegues del manto son perfectamente visibles y se dirigen hacia el centro de la figura, donde el indumento es sujeto con las manos cubiertas, como también un objeto alargado que reposa sobre el brazo izquierdo y cuya parte superior algo más ancha se ha perdido.

La iconografía del objeto puede interpretarse como una representación anubíaca relacionada con los cultos egipcios que parten de Egipto desde época helenística y que tienen una gran difusión en el Imperio romano hasta época tardoantigua, cuando comienza su declive (sobre los cultos egipcios en época romana cf., por ejemplo, Alvar, 2008; Bricault, 2013; Dunand, 1973; Malaise, 1984; Witt, 1971).

La cabeza del cánido de la terracota es la de un chacal, con sus orejas erguidas y los cabellos en el cuello perfectamente representados. Este es un animal vinculado a Anubis, una divinidad funeraria muy importante en el antiguo Egipto y bastante presente en el Mediterráneo romano acompa-

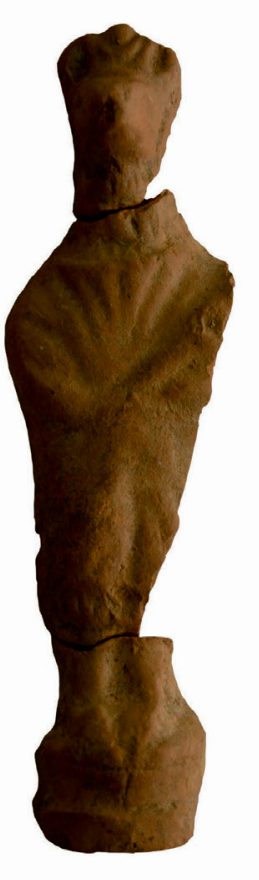

a)

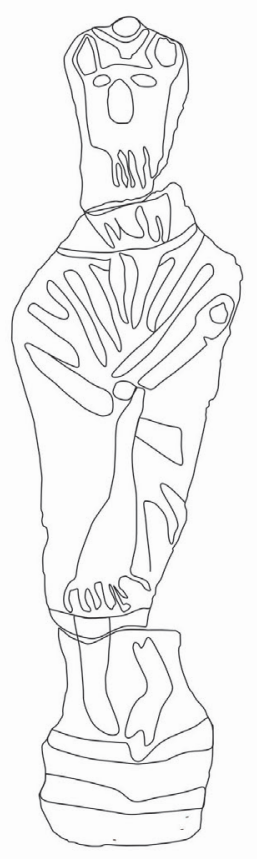

b)

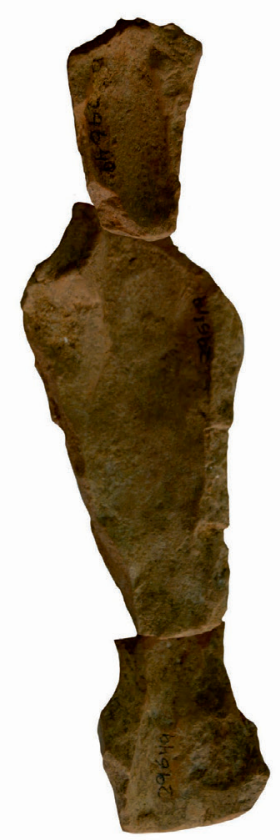

c)

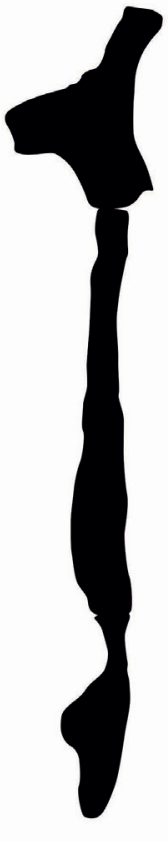

d)

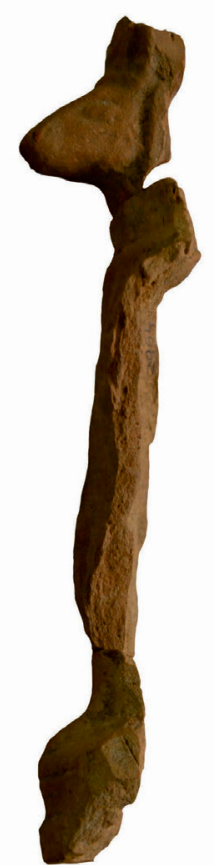

e)

Figura 6. a) Vista frontal de la representación; b) dibujo del frontal; c) vista trasera de la terracota; d) sección de la pieza y e) vista lateral de la pieza. 
ñando a Isis (Altenmüller, 1975; Grenier, 1977). El tocado sobre la cabeza de chacal es un basileion isíaco de origen hathórico que, como elementos fundamentales, está compuesto de una luna creciente y un disco solar (Malaise, 2009). Esta forma de representar la cabeza anubíaca comparte modelo con la conocida escultura romana de Anubis encontrada en la Villa Pamphi-li, hoy en el Museo gregoriano vaticano (Malaise, 1972) (Figura 7).

El manto completamente cubriente no está presente en gran parte de las imágenes de Anubis y los sacerdotes anubíacos del Occidente mediterráneo (Bricault, 2001b), que suelen llevar solamente una túnica (Leclant, 1981), como tampoco es exclusivo de los sacerdotes con máscara de Anubis (Albersmeier, 2018). Sin embargo, el color rojo del manto sí es un rasgo vinculado al dios y los oficiantes con máscara de chacal ya en el propio Egipto (Klotz, 2012: 392-394). En cuanto al objeto que aparece en las manos del personaje de la terracota que estudiamos, a priori, pudiera pensarse que se trate de un caduceo o una antorcha.

La terracota presentaría originalmente policromía, hoy perdida algo muy normal en la coroplastia romana (Blanchet 1983: 77). Los colores serían similares a los que encontramos en imágenes de

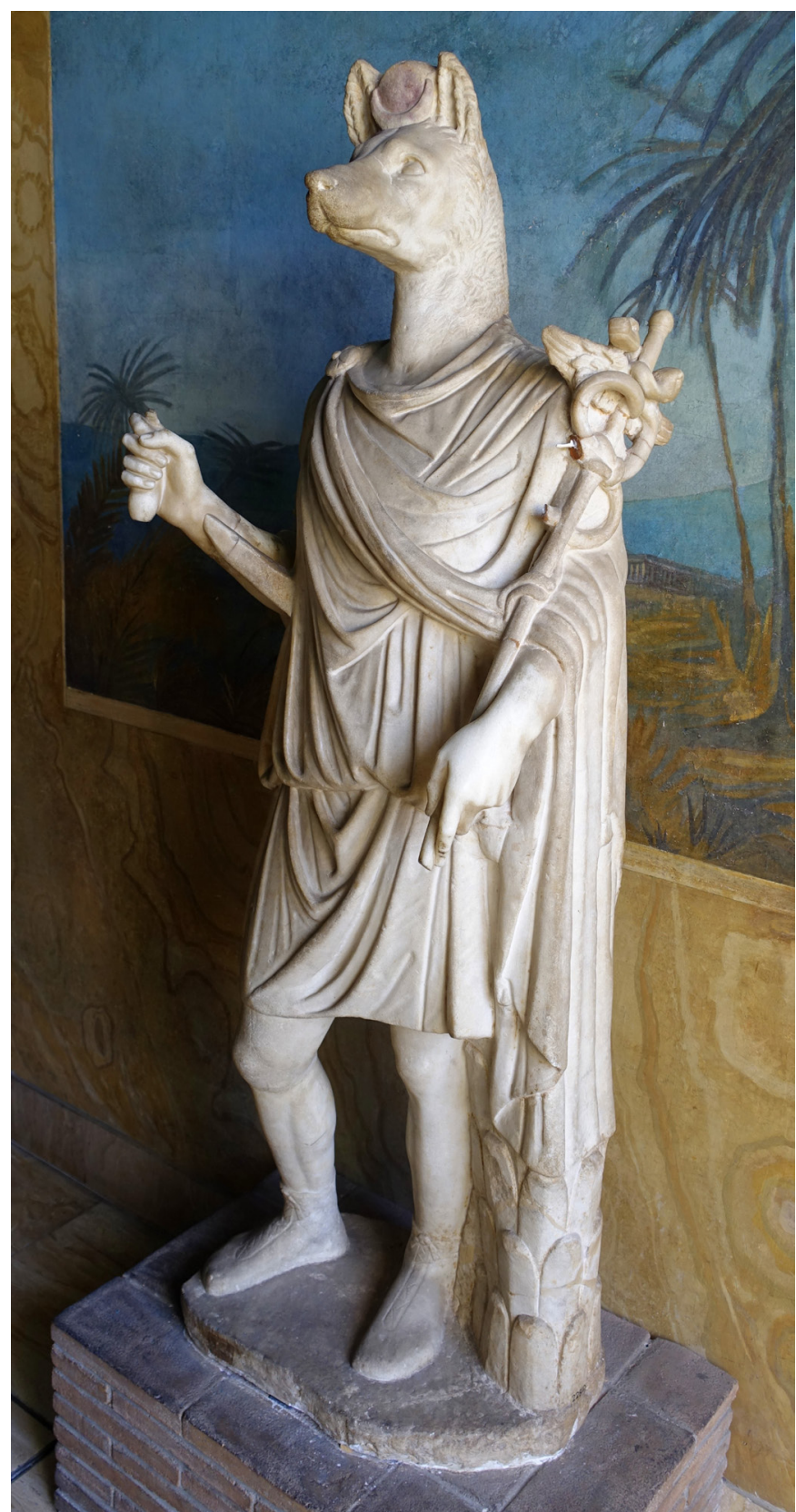

Figura 7. Escultura de Anubis en el Museo gregoriano vaticano. (Fuente: Wikimedia Commons. Dominio público). 
sacerdotes anubíacos en pinturas itálicas, pero también en fuentes iconográficas del Egipto romano. Sin embargo, el desgaste de la pieza ha hecho que se perdiera, como mínimo: el negro de la cabeza animal, el rojo del manto o el color de la piel de las piernas del sacerdote (en el caso de que fuese lo representado). Como ejemplo de la policromía que tendrían este tipo de terracotas se puede traer a colación un ejemplo del Egipto grecorromano en la colección Fouquet (al menos a principio del s. XX), en el que puede verse una amplia gama de colores en una figura de Anubis con manto que es portada por dos sacerdotes (Figura 8).

\section{Aspectos conclusivos}

Más allá de los motivos concretos de la terracota protagonista de este artículo es interesante ver cuán común es su iconografía en el contexto de los cultos isíacos del Mediterráneo occidental y concretamente de la península ibérica. Cabe empezar haciendo hincapié en que las imágenes de Anubis y los sacerdotes con máscara de chacal aparecen por muchas partes del territorio dominado por los romanos en forma de escultura o incluidas en piezas de cerámica o monedas, por ejemplo (Grenier, 1977; Bricault ,2001a; Podvin, 2001; Podvin, 2003; Podvin, 2005; Bricault, 2008). En cualquier caso, son menos frecuentes las imágenes anubíacas que aquellas de la diosa Isis y sus sacerdotisas, que también están más presentes en las fuentes literarias (Walters 1988; Tran tam Tinh, 1990; Eingartner 1991; Bricault, 2001; Ortiz, 2011; Bricault, 2013; Bricault, 2018; Malaise y Veymiers, 2018; Moormann, 2018). En muchas ocasiones encontramos representaciones de Anubis en compañía de Isis y Harpócrates en distintos medios, pero de forma aislada es más complicado verlo. Además, hasta donde conocemos, terracotas como la presentada en este trabajo no han sido publicadas con anterioridad y en el caso de piezas del Egipto grecorromano, lo habitual es ver al dios en el marco de alguna escena, siendo portado por sacerdotes o junto a otros dioses como Osiris o sacerdotes di-

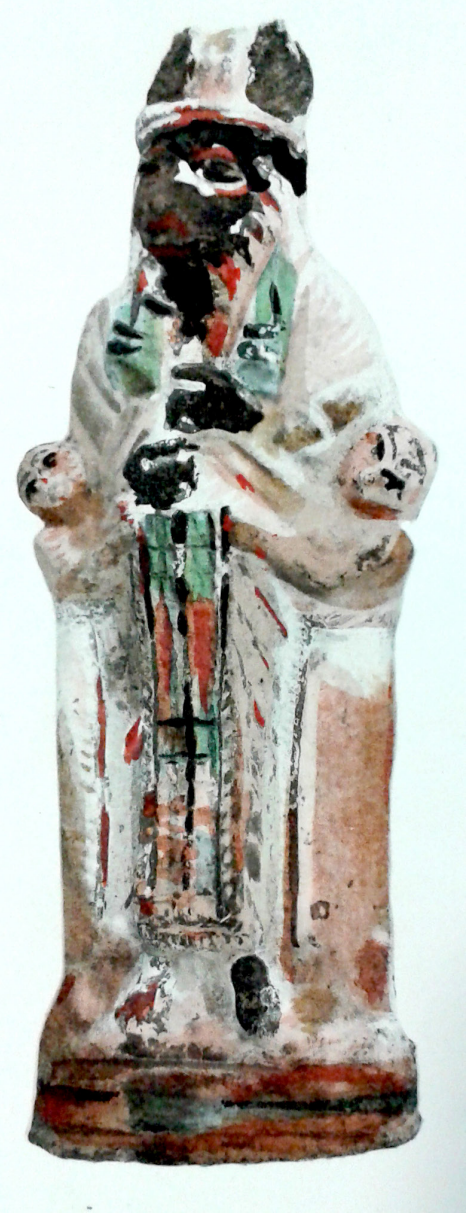

Figura 8. Terracota con dos sacerdotes portando una imagen de Anubis.

(Fuente: Perdrizet, 1921b: lám. I). 
versos (por ejemplo: Perdrizet, 1921) (Figura 8).

En el caso de Egipto, las representaciones de Anubis y sacerdotes con máscara de chacal llevando manto rojo son antiguas (Klotz, 2012), e incluso tenemos un ejemplo de máscara de chacal conservada en el Roemer- und Pelizaeus-Museum de Hildesheim (no inv. 1585) (Wolinski, 1986; Wolinski, 1987). No obstante, centrándonos en las imágenes similares y cercanas tanto geográfica- como cronológicamente a la estudiada en este trabajo, hay dos casos que son interesante citar: por un lado, un fresco que se dispuso en el pórtico del templo de Isis en Pompeya y que hoy en día se encuentra en el Museo arqueológico nacional de Nápoles ( $\mathrm{n}^{-}$ inv. 8920) (Elia, 1941) (Figura 9); y, por otro lado, una basa con inscripción e iconografía encontrada en Guadix y que hoy en día se halla en el Museo arqueológico de Sevilla (no inv. REP08369) (Alvar,
2012) (Figura 10).

El fresco del Iseo pompeyano (s. I d.C.) (Figura 9) muestra una figura muy similar a nuestra terracota: un personaje con cabeza de chacal negra, aunque representada de modo realista y sin tocado; que viste una indumentaria cuyo elemento principal es un manto rojo completamente cubriente, pero que también incluye unas sandalias blancas. Este testimonio es importante porque dentro del repertorio de representaciones anubíacas del Occidente mediterráneo, es de las pocas que conserva coloración. Esto resulta relevante por dos razones: confirma tanto que se trata de un sacerdote emulando al dios Anubis por el color de la piel de los pies que contrasta con el negro de la cabeza, como que el manto era rojo estaba ligado a estas figuras como en origen, en Egipto. En cualquier caso, al no llevar ningún objeto, nos informa

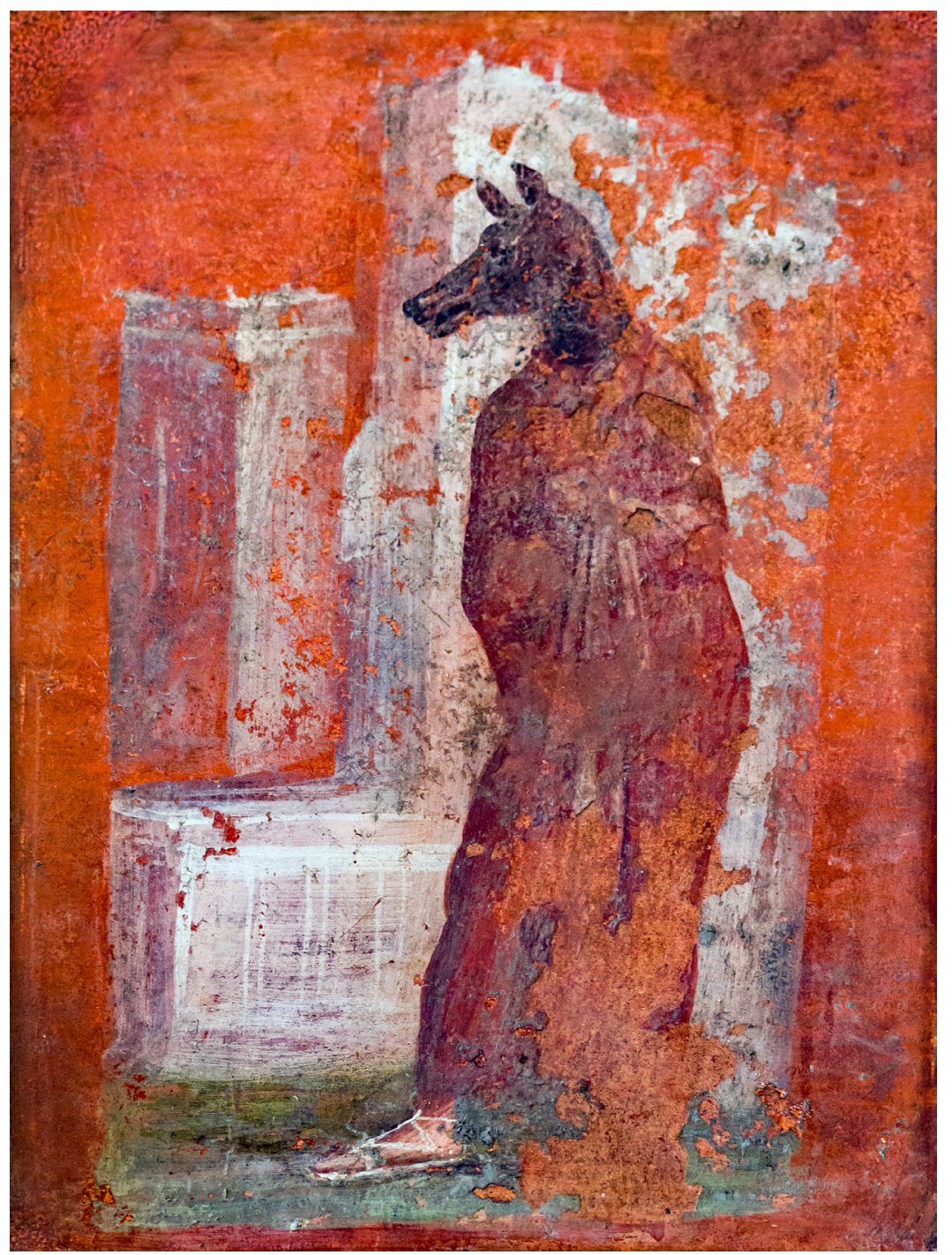

Figura 9. Sacerdote anubíaco representado en el templo de Isis en Pompeya. (Fuente: commons.wikimedia.org/ wiki/File:Wall_painting_-_phantastic_architecture_with_pictures_-_Pompeii_(VIII_7_28_-_sanctuary_of_Isis_-_porticus)_-_Napoli_MAN_-_38.jpg. Autor: ArchaiOptix. Licencia: CC BY-SA 4.0 (creativecommons.org/licenses/bysa/4.0/deed.en)).

Revista Atlántica-Mediterránea de Prehistoria y Arqueología Social 22, pp. 209-227 


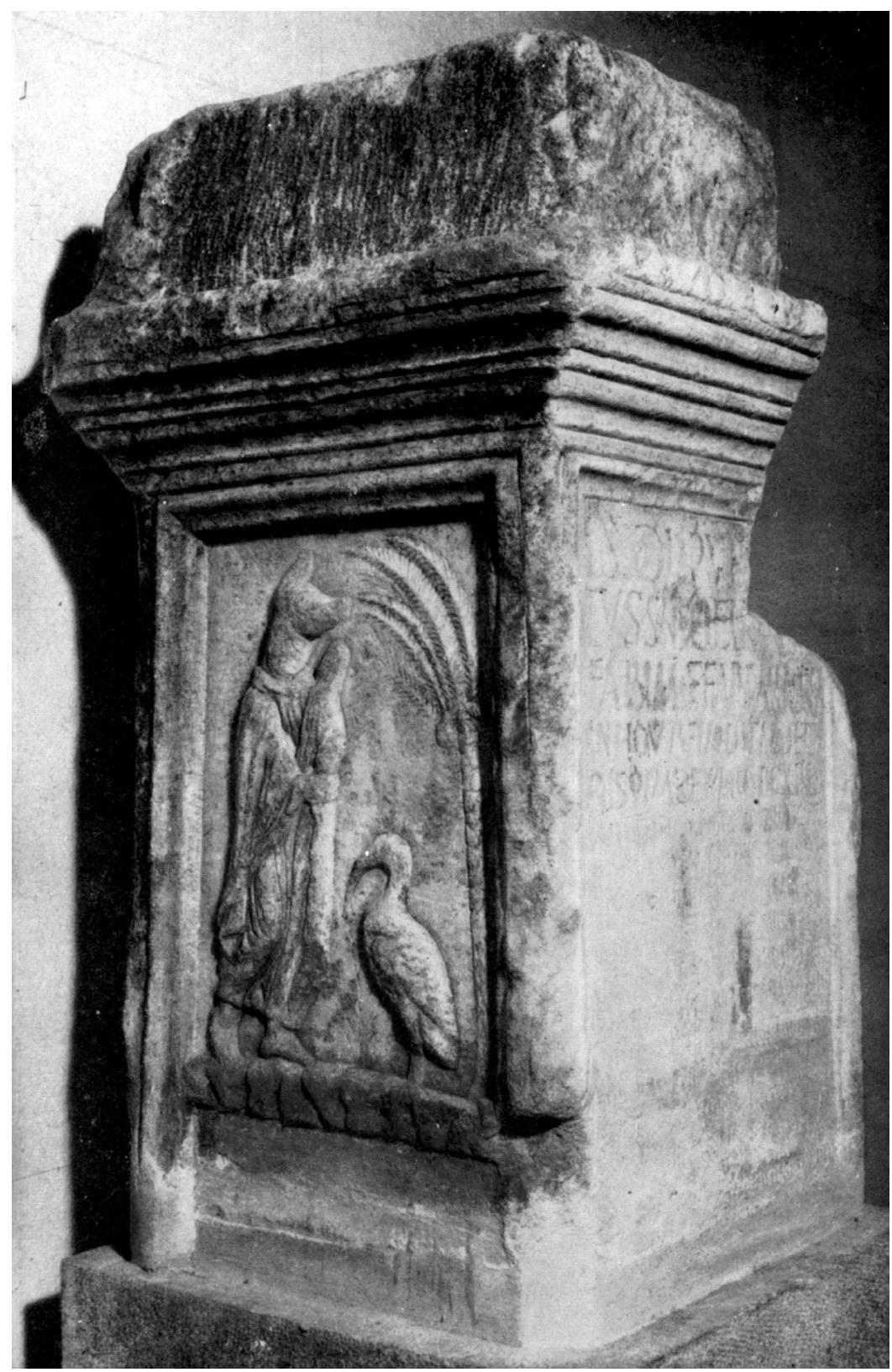

Figura 10. Basa con representación anubíaca encontrada en Guadix.

(Fuente: García y Bellido, 1967: lám. XI).

también de que estas figuras podían portar o no símbolos en sus manos en el marco de su papel en los rituales.

En segundo lugar, y como testimonio más cercano geográfica- e iconográficamente, tenemos la basa de Guadix que aparte de una inscripción dedicatoria ampliamente estudiada (Alvar, 2012), también está decorada con escenas de inspiración egipcia que recuerda a los paisajes nilóticos (cf. Versluys, 2002). En esta ocasión, únicamente, nos detendremos en una de estas escenas que ocupa una de las caras de la pieza, y que está protagonizada por una representación anubíaca (Figura 10).
El entorno idílico en el que se encuentra esta figura viene marcado por la presencia de un ave, una especie de arbusto y una palmera situados en un entorno de suelo rocoso, en el que aparece caminando a una figura con cabeza de chacal, aunque de nuevo, como ocurre con el fresco pompeyano, sin tocado alguno sobre la cabeza. El atuendo de este personaje consiste en una túnica larga que llega hasta los tobillos de unos pies calzados y un manto encima que en el acto de moverse deja la parte frontal de la figura sin cubrir. Lo más interesante en lo referente al estudio iconográfico de este trabajo es que la figura anubíaca de Guadix 
lleva un objeto en las manos con decoración de líneas paralelas que tiene la misma forma y está cogido del mismo modo que aquel que encontramos en la terracota de Cádiz. Entre las interpretaciones modernas que se le han dado al objeto que porta la figura anubíaca de Guadix está: una antorcha (García y Bellido, 1967) y "una imagen divina velada, un Osiris-Canopo, transportado sobre una columnita" (Alvar, 2012, 2016). Nosotros creemos como García y Bellido, que en ambos casos se trata de la representación de una antorcha y no de un Osiris-Canopo sobre una columna como ha sido propuesto más recientemente. Para la propuesta de la antorcha podemos remitir a un paralelo en un retrato de momia de Antinoopolis (Egipto) en época romana en el que aparece una mujer con el mencionado objeto (Ortiz, 2020) (Figura 11). Este tiene un patrón de líneas paralelas que remiten a su composición vegetal y que es portado de forma parecida al caso de la terracota gaditana. También podemos remitir a imágenes de Isis-Termutis con antorchas (Figura 12). Descartamos que pueda tratarse de un vaso de Osiris-Canopo sobre una columnita porque dichos recipientes son llevados directamente en las manos cubiertas, como puede verse, por ejemplo, en columnas del Iseo del Campo de Marte en Roma con sacerdotes llevando estos instrumentos rituales (Roullet, 1972: 57-58 no 16-19, figs. 39, 43, 45-46). Además, esa forma inclinada de llevar el objeto es más típica de las antorchas y atendiendo a razones prácticas tampoco sería posible portar un vaso sobre una columna por el peso que tendría el objeto.

A esta interpretación iconográfica hay que unirle el lugar del hallazgo, Gades. La presencia de elementos egiptizantes en el solar de la actual Cádiz no es un fenómeno aislado. La presencia fenicia, claramente, fue elemento vehicular entre el extremo oriental y el Mediterráneo occidental. Estas representaciones, mayoritariamente, se incluyen en la esfera de lo funerario/votivo con una amplia proliferación de los amuletos de corte egiptizante como escarabeos, escarabeoides o representaciones de divinidades muy concretas, caso de Bes. Este fenómeno se acrecienta a partir del VI a.C. y durante todo el V a.C. (Jiménez, 2004). Aunque inicialmente este tipo de piezas fueron, posiblemente, egipcias o manufacturadas por artesanado egipcio bajo la órbita fenicia, no hay que descartar la posible reinterpretación iconográfica por artesanos locales de la franja siriopalestina o bien del extremo occidental.
Aunque no es nuestro cometido desarrollar una exégesis sobre la presencia de aegyptiaca en suelo gadirita sí es de interés mostrar algunos ejemplos de carácter antropoformos como es nuestro caso pero en momentos más antiguos. El ejemplo más reiterado es el de Bes con buenos ejemplares en fayenza procedentes del entorno de la Playa de Santa María (Gamer, 1978), la casa del Pino, Avenida de Andalucía 2 y plaza de la Constitución 1 o ya una pieza en un contexto plenamente romano conformado por una cuenta de pasta vítrea flanqueada por abalorios fálicos localizado como depósito en un ánfora infantil de la Avenida de Andalucía (Perdigones, Troya o Muñoz, 1987). En la intervención de avenida Lo mismo ocurre con un amuleto con figuración cercana a Bes localizado en la tumba 49 de la c/García Escámez que, de nuevo, apareció en un contexto claro de época romana (García, 2001).

Junto con la representación de Bes que, podría caracterizarse como la más numérica en hallazgos, también aparecen otras divinidades del panteón egipcio pero con un menor impacto caso de Thueris, Sekhmet, Bastet, Neftis o Hathor (Jiménez, 2004).

En lo que se refiere a la divinidad que ahora nos centra, Anubis, únicamente tenemos un posible ejemplar en la tumba 1 de la necrópolis de Tolosa Latour datada en el VI a.C. En concreto, formando parte del depósito, se localizó un engaste de anillo áureo donde aparecía una representación infantil sobre flor de loto, cetro w3d y cabeza de chacal (Perdigones et al., 1990).

Frente a esta intensa proliferación de representaciones en época fenicia la situación parece cambiar en época romana. Además de los escasos ejemplos de amuletos a los que anteriormente hemos hecho alusión previamente y que, claramente, podrían considerarse como elementos de larga perduración en el tiempo, hay que unirle algunas piezas cerámicas que ahondan en el intenso tránsito comercial que se desarrolló en ambos extremos del Mediterráneo. Claro ejemplo de lo indicado sería la pareja de cráteras de fayenza del I d.C. localizadas en la Avda. de Andalucía no 21-27 (Inventario CERES no DJ25272.) y asociadas al taller de Kom Hellul, Menfis (Amores, 2002: 51, fig. 8).

Para la península ibérica no contamos con demasiadas terracotas relacionadas con los cultos egipcios (p. ej. Alvar, 2012: 111 [no. 157]) y ninguna anubíaca había sido publicada hasta la fecha. Por otro lado, en suelo hispano solo la imagen de 
BUSTAMANTE ÁLVAREZ, Macarena, GARCÍA PANTOJA, Ma Eugenia, ORTIZ GARCÍA, Jónatan y MARTÍN MARTÍNEZ, Sandra

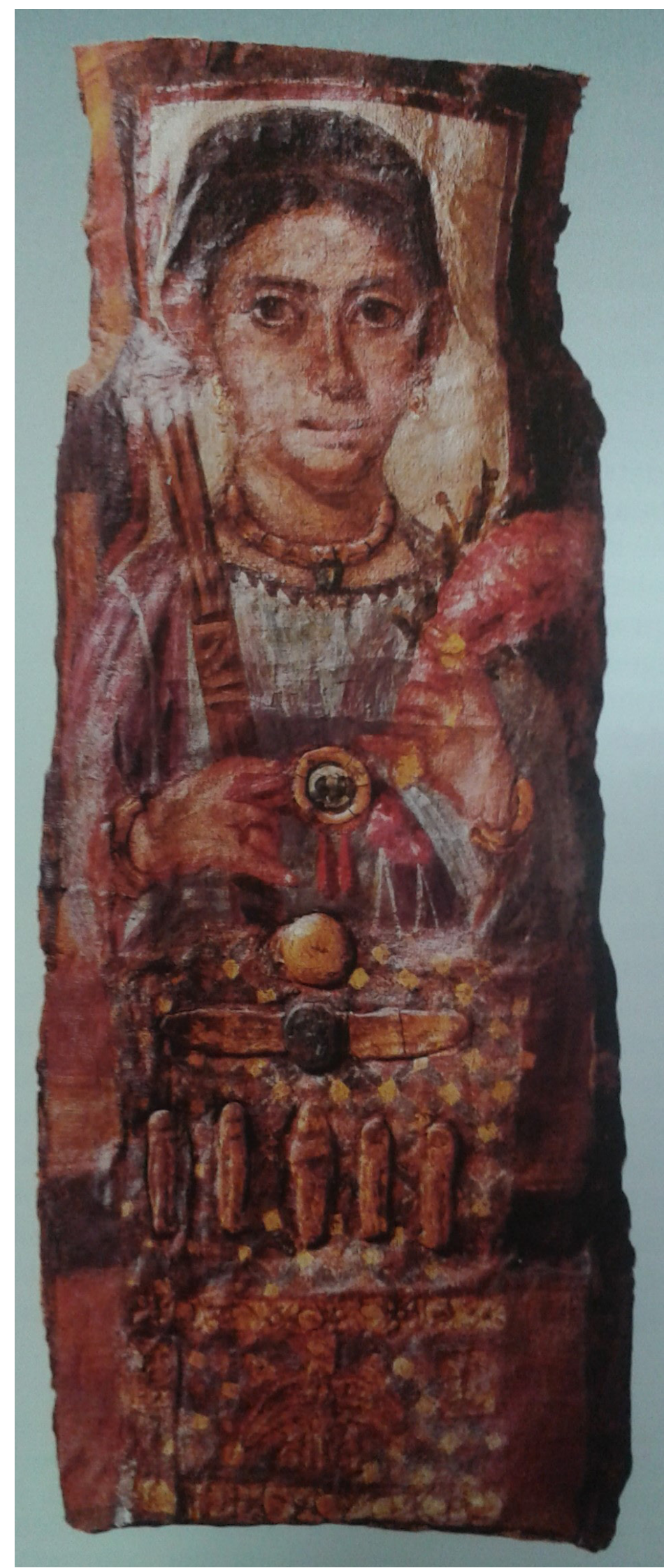

Figura 11. Retrato de mujer con antorcha de Antinoopolis. (Fuente: Wiese y Page-Gasser, 1997: fig. 215). 


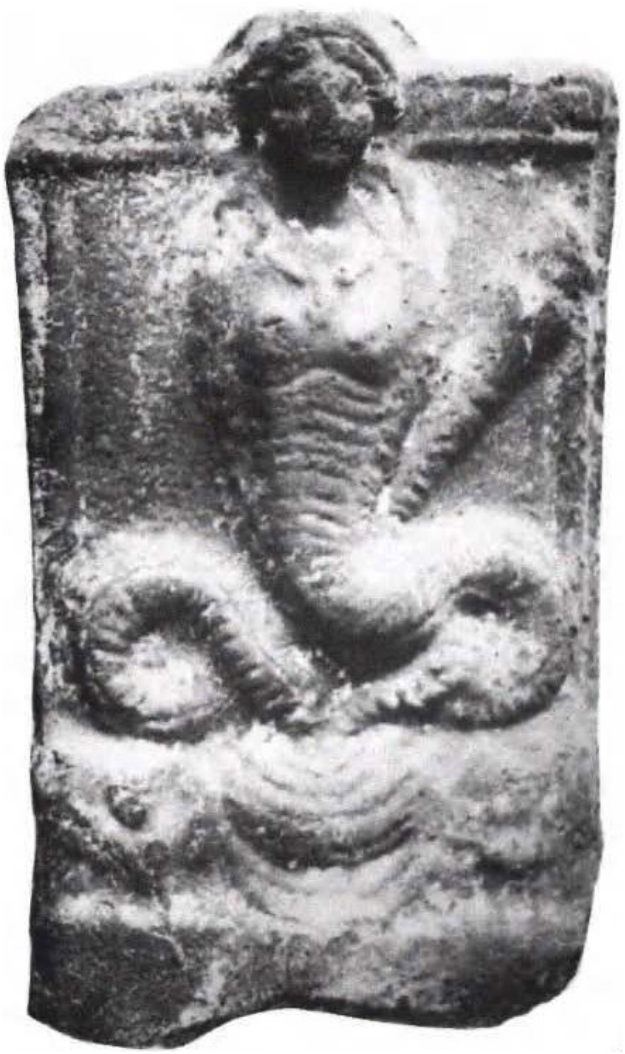

Figura 12. Isis-Termutis con antorcha. (Fuente: Knauerm 1995: fig. 41).

la basa de Guadix a la que anteriormente hemos hecho alusión presenta una similitud a la terracota que publicamos, mientras el resto de representaciones peninsulares de Anubis conocidas hasta ahora son más bien del tipo más común vestido a la romana sin manto cubriente y llevando palmas o caduceos generalmente (ver Alvar, 2012). La iconografía de esta divinidad del panteón romano gozó de una intensa proliferación en suelo peninsular, sobre todo, en soporte cerámico. Especialmente, son resaltable dos categorías donde, de manera muy recurrente, se usa su representación: las sigillatas así como las lucernas.

En relación a las primeras, las sigillatas de producción tanto norteña como sureña, son múltiples los ejemplos que invaden los registros decorativos tanto de formas abiertas como cerradas. En cuanto al número de punzones un reciente estudio ha delimitado 16 representaciones iconográficas diversas adscritas a cuatro grandes grupos que se diferencia por su esquematismo en la representación así como por la representación de diversos atributos (Sáenz y Prieto, 2015). Quizás los más comunes en suelo peninsular corresponden a los que aparece una figura con toga corta muy historiada y portando con la mano derecha un caduceo y a la izquierda una rama vegetal (Garabito y So- lovera, 1976, fig. 2, n‥ 7; Garabito, 1978, pl. 4, no․ 8; Mayet, 1984, pl. 54, no. 324, y pl. 192, no. 2250; Mezquíriz, 1961, pl. 56, no. 246 o Bustamante- Álvarez, 2013, pl. 186, no 1). La figura antropomorfa aparece descalza y presenta prótomo de chacal. En esta representación en concreto, desconocemos si estamos ante un anubóforo o si, por el contrario, nos encontramos frente a la personificación híbrida del propio dios por el largo cuello que se acercaría más a la figura animal que a una personificación. Además de los ejemplos localizados en sus propios centros productores, también se ha localizado un interesante ejemplar sobre una jarra en Badarán -La Rioja- donde la representación aparece junto con Isis con la que formaría pareja (Martínez, 2002).

Digno de mención es un ejemplar localizado en Silchester, sito en la antigua provincia de Britannia (Bustamante y Bird, 2015) de gran interés, por su lejanía al hinterland natural de exportación de estas sigillatas pero, además, por proceder de un contexto de corte militar. Esto supone, claramente una intencionalidad por portar un vaso con una representación muy específica que quizás iría en consonancia con una confesión muy concreta del utilitario.

Tanto en las sigillatas como en las lucernas es- 
tas representaciones se pueden considerar como muy esporádicas pero de interés por la significación que acarrean. Es evidente que, frente a las posibles prohibiciones para temas egipcianos que el Imperio sufre en la primera mitad del I d.C. (Witt, 1971), hay que valorar la revitalización de una corriente filoegipcia que alcanzará su máxima expresión con los antoninos (Witt, 1971). A este respecto, la presencia de este tipo de símbolos en objetos cotidianos supone una clara democratización de unos productos altamente apreciados por la élite. Por lo tanto, estas representaciones en soportes comunes podrían ser una práctica que permite emular de manera más asequible la moda imperante de la clase alta atraída por estos productos que podríamos haber tipificado como "exóticos". Sin embargo, en las representaciones sobre sigillatas o en lucernas una de las características fundamentales que se aprecia es la adaptación a estas divinidades de atuendos y simbología claramente romana, caso del caduceo que, recurrentemente, porta Anubis. De hecho, en el caso del binomio divino Isis-Anubis, algunos autores apuntan a la asimilación de la pareja Venus-Mercurio que nos hablaría de un sincretismo más focalizado en la estética que en la idiosincrasia propiamente dicha (Martínez, 2002). A este respecto este tipo de representaciones recibieron el nombre de Hermanubis por su hibridación.

En cuanto a las lucernas las representaciones varían sensiblemente ya que, habitualmente forman triada con otras divinidades como con Isis y Harpócrates y en menor medida sólo con Isis (http://biblioteca3.uc3m.es/Gens-Isiaca-Hispania/consulta.php? consulta=anubis (consulta hecha el 23 de septiembre de 2020).

En ambos casos, tanto en lucernas como en sigillatas, las representaciones aparecen como aderezo ornamental o simbólico de la pieza, esto es, que la pieza en sí misma podría haber contenido o no esta representación. Sin embargo, el objeto que ahora presentamos posee una problemática muy diversa. En primer lugar, que aparece representada sola por lo que no daría pie a ninguna asociación a la que anteriormente nos hemos referido. En segundo lugar, que la representación no aparece como elemento decorativo sino que, la figura se mimetiza con el objeto en sí. Esto además, nos permite reflexionar sobre el hecho de que, cuando un comprador decide adquirir una pieza en sigillata o una lucerna lo hace con fines utilitarios muy concretos -consumo o servicio de alimentos o iluminación-. Evidentemente, su decisión se puede ver condicionada por un tipo de representación iconográfica pero el fin último de la pieza es otro que sobrepasa los límites puramente religiosos.

En el caso concreto que ahora valoramos, la pieza en sí mismo es la representación de Anubis o de un anuboforo por lo que el que se decantara por adquirir dicho elemento lo haría teniendo presente que este tipo de objetos únicamente servían para evocar una realidad supraterrenal que conocerían y a la cual tendrían cierto aprecio.

Como ya se ha indicado previamente este tipo de representaciones, las terracotas, no son habituales en suelo hispano lo que le añade un mayor interés a la pieza. A falta de análisis arqueométricos no podemos precisar la procedencia de la pieza, sin embargo, a priori, macroscópicamente pensamos que sería foránea de posible origen oriental y la débil impresión de la pieza, claramente, apunta a una sobreutilización del molde. Ante esto y como hipótesis de partida esta pieza fue adquirida fuera de los límites de Gades y traída bien por simples contactos comerciales, como memento de un lugar lejano o bien por convicciones religiosas.

De igual modo, su contexto de aparición en un edificio que podría tipificarse como comercial o artesanal por las estructuras a las que previamente hemos aludido, podría darnos las pistas del por qué de su aparición en el solar gaditano. A este respecto ya hemos valorado la cercanía que se llegó a establecer entre Mercurio y Anubis en el panteón romano occidental. La presencia de esta divinidad protectora del comercio y de las transacciones económicas pudo ser una figura votiva que terminó tutelando las actividades artesanales allí desarrolladas. Es evidente que, quienes usaron esta figura, conocían a quién se estaban invocando $y$, aunque la representación de Anubis y su culto estaba ampliamente difundida en suelo hispano no descartamos la posibilidad de que fueran comerciales orientales más cercanos y afines a esta idiosincrasia los que regentasen este lugar.

Dado que la terracota gaditana no sabemos si se encuentra en su contexto de uso primario (al aparecer como vertido en una zanja de expolio), e incluso le faltan los colores que tendría en origen, es complicado establecer si se trata de una representación del propio dios Anubis o un sacerdote anubóforo, de los que hay testimonios iconográficos y textuales para época romana (Bricault, 2001b). Un elemento que nos hubiera podido ser de ayuda al respecto hubiera sido el color de los pies (ne- 
gros en el caso de una representación del dios). Sin embargo, solo contamos con un elemento que podría aportar algo a esta discusión: el basileion isíaco sobre la cabeza. No obstante, como se ha visto en el pasado para las representaciones de Isis y sus seguidoras (sacerdotisas o meras devotas), la presencia del basileion sobre la cabeza no es un rasgo que nos pueda asegurar que nos encontramos ante una representación de una divinidad y no de un/a oficiante (Ortiz, 2011). Por tanto, es difícil poder determinar si se trata del dios chacal o un sacerdote con atuendo anubíaco. Desde un punto de vista únicamente iconográfico, a favor de una identificación como divinidad podríamos aducir que cuando encontramos la imagen en terracotas en suelo egipcio, la imagen representada con cabeza de chacal y manto cubriente es aquella del dios Anubis y no un oficiante. Un ejemplo de esto es una pieza mencionada anteriormente en la que aparecen dos sacerdotes llevando una imagen del dios con el mismo atuendo que aparece en la terracota de Cádiz (Figura 8). El objeto de la mano en la terracota gaditana no es algo que pueda esgrimirse para determinar que se trata de un sacerdote, puesto que también el dios lleva objetos en las manos, aunque generalmente se trate de palmas y caduceos, como ya hemos comentado.

Finalmente, dejando sin responder la cuestión del carácter divino o no de la figura representada, queremos mencionar que una problemática todavía mayor se plantea al intentar determinar el uso religioso concreto del objeto, teniendo en cuenta que el contexto arqueológico en el que la pieza fue hallada no es elocuente al respecto. No obstante, es probable que se usara como parte de una celebración (¿una procesión?), como ex voto o como objeto de culto en una esfera más privada. Nuevos datos de la zona arqueológica puede que nos ayuden al respecto en el futuro.

\section{Bibliografía}

ALBERSMEIER, Sabine. 2018: "The Garments of the Devotees of Isis". En V. GASPARINI y R. VEYMIERS (eds.): Individuals and materials in the Greco-Roman cults of Isis: agents, images, and practices. Proceedings of the VIth International Conference of Isis Studies (Erfurt, May 6-8, 2013 - Liège, September 23-24, 2013), pp. 448-469. Brill. Leiden - Boston.

ALTENMÜLLER, Brigitte. 1975: "Anubis". En W. HELCK y E. OTTO (eds.): Lexikon der Ägyptolo- gie I: A-Ernte, pp. 327-333. Otto Harrassowitz. Wiesbaden.

ALVAR EZQUERRA, Jaime. 2008: Romanising oriental Gods: myth, salvation and ethics in the cults of Cybele, Isis and Mithras. Brill. Leiden.

ALVAR EZQUERRA, Jaime. 2012: Los cultos egipcios en Hispania. Presses universitaires de Franche-Comté. Besançon.

ALVAR EZQUERRA, Jaime. 2016: "Agua fresca para Avita y joyas de inmortalidad para Isis (CIL II 3386)". Dialogues d'histoire ancienne, 42.1, pp. 201-218.

AMORES CARREDANO, Fernando. 2002: Cádiz al fin del milenio. Cinco años de arqueología en la ciudad (1995-2000). Museo de Cádiz. Cádiz.

BLANCHET, Adrien. 1983: Les figurines en terre cuite du la Gaule romaine. Revue d'Archeologie Sites.

BRICAULT, Laurent. 2001a: Atlas de la diffusion des cultes isiaques (IVe s. av. J.-C. - IVe s. apr. J.-C.). Diffusion de Boccard. París.

BRICAULT, Laurent. 2001b: "Les Anubophores". Bulletin de la Société d'Égyptologie de Genève, 24, pp. 29-42.

BRICAULT, Laurent. 2008: "Anubis". En L. BRICAULT (dir): Sylloge nummorum religionis isiacae et sarapiacae (SNRIS), pp. 76-78. De Boccard. París.

BRICAULT, Laurent. 2013: Les cultes isiaques dans le monde gréco-romain. Les Belles Lettres. París.

BRICAULT, Laurent. 2018: "Les prêtres isiaques du monde romain". En V. GASPARINI y R. VEYMIERS (eds.): Individuals and materials in the Greco-Roman cults of Isis: agents, images, and practices. Proceedings of the VIth International Conference of Isis Studies (Erfurt, May 6-8, 2013 - Liège, September 23-24, 2013), pp. 155197. Brill. Leiden - Boston.

BUSTAMANTE ÁLVAREZ, Macarena. 2013: Terra sigillata hispánica en Augusta Emerita. Revisión tipocronológica a partir de las evidencias del Suburbium Norte. Anejos de Archivo Español de Arqueología 65,.Mérida.

BUSTAMANTE ÁLVAREZ, Macarena; BIRD, Joan. 2015: "Finds of Spanish Samian Ware (Terra Sigillata Hispanica)”. Britannia, 46, pp. 262266.

DUNAND, Françoise. 1973: Le culte d'Isis dans le bassin orientale de la Méditerranée. Brill. Leiden.

EINGARTNER, Johannes. 1991: Isis und ihre Diene- 
rinnen in der Kunst der römischen Kaiserzeit. Brill. Leiden-Nueva York-Copenhague-Colonia.

ELIA, Olga. 1941: Le Pitture del Tempio di Iside. Libreria dello Stato. Roma.

GAMER WALLERT, Ingrid. 1978: Ägyptische und ägyptisierende Funde von der iberischen Halbinsel. Tübinger Atlas des Vorderen Orients (TAVO).

GARABITO GÓMEZ, Tomás; SOLOVERA SAN JUAN, María Esther. 1976: Tricio II: marcas de alfarero. Studia Arqueologica 40. Valladolid.

GARABITO GÓMEZ, Tomás. 1978: Los alfares romanos riojanos: producción y comercialización. Instituto Espanol de Prehistoria, Consejo Superior de Investigaciones Científicas. Madrid.

GARCÍA MARTÍNEZ, Miguel Ángel. 2001: Documentos prerromanos de tipo egipcio de la vertiente atlántica hispano- mauritana. Vols. 1 y 2. Université Paul-Valéry. Montpellier.

GARCÍA y BELLIDO, Antonio. 1967: Les religions orientales dans l'Espagne romaine. Brill. Leiden.

GÓMEZ PEÑA, Álvaro; RODRÍGUEZ MELLADO, Jesús. 2014: "A propósito de dos nuevos amuletos de Bes procedentes de Chipiona y Rota", SPAL, 23, pp. 147-165.

GRENIER, Jean-Claude. 1977: Anubis alexandrin et romain. Brill. Leiden.

HENDERSON, Julián, 1991: "Technological, Characteristics of Roman Enamel". Jewellery Studies, vol. 5, págs. 64-76.

JIMÉNEZ FLORES, Ana María. 2004: “Aegyptiaca: datos sobre la espiritualidad en la necrópolis de Gadir". SPAL, 13, pp. 139-154.

KLOTZ, David. 2012: "The lecherous pseudo-Anubis of Josephus and the "Tomb of 1897" at Akhmim". En A. GASSE, F. SERVAJEAN y C. THIERS (eds.): Et in Aegypto et ad Aegyptum: recueil d'études dédiées à Jean-Claude Grenier 2, pp. 383-396. Université Paul Valéry (Montpellier III). Montpellier.

KNAUER, Elfriede Regina. 1995 : Urnula faberrime cavata: observations on a vessel used in the cult of Isis. B. G. Teubner. Stuttgart.

LECLANT, Jean. 1981: "Anubis". LIMC, I, pp. 862873.

MALAISE, Michel. 1972: Inventaire préliminaire des documents égyptiens découverts en Italie. Brill. Leiden.

MALAISE, Michel. 1984: "La diffusion des cultes égyptiens dans les provinces européennes de l'Empire romain". ANRW, II.17.3, pp. 1615-
1691.

MALAISE, Michel. 2009: "Le basileion, une couronne d'Isis: origine et signification". En W. CLAES, H. DE MEULENAERE y S. HENDRICKX (eds.): Elkab and beyond: Studies in honour of Luc Limme, pp. 439-455. Peeters. Lovaina.

MALAISE, Michel; VEYMIERS, Richard. 2018: "Les dévotes isiaques et les atours de leur déesse". En V. GASPARINI y R. VEYMIERS (eds.): Individuals and materials in the Greco-Roman cults of Isis: agents, images, and practices. Proceedings of the VIth International Conference of Isis Studies (Erfurt, May 6-8, 2013 - Liège, September 23-24, 2013), pp. 470-508. Brill. Leiden - Boston.

MARTÍNEZ GONZÁLEZ, Milagros. 2002: "Jarra de terra sigillata hispánica con decoración isíaca encontrada en Badarán (La Rioja)". Iberia, 5, pp. 207-216.

MAYET, Françoise. 1984: Les céramiques sigillées hispaniques. Contribution à l'histoire économique de la Péninsule Ibérique sous l'Empire romain. Publications du Centre Pierre Paris 12/ Collection de la Maison des Pays Ibériques 21 (2 vols). París.

MCINTOSH, Fiona, 2009: A study into Romano-British enamelling -with a particular focus on brooches. The School of Historical Studies Postgraduate Forum E-Journal, Edition 7.

MEZQUÍRIZ DE CATALÁN, María Ángeles. 1961: Terra sigillata hispánica. Valencia.

MOORMANN, Eric M. 2018: "Ministers of Isiac Cults in Roman Wall Painting". En V. GASPARINI y R. VEYMIERS (eds.): Individuals and materials in the Greco-Roman cults of Isis: agents, images, and practices. Proceedings of the VIth International Conference of Isis Studies (Erfurt, May 6-8, 2013 - Liège, September 23-24, 2013), pp. 366-383. Brill. Leiden - Boston.

ORTIZ GARCÍA, Jónatan. 2011: "La pervivencia de elementos de la indumentaria e identidad egipcias en la iconografía grecorromana: el caso de Isis". En C. Alfaro, J. Martínez y J. Ortiz (eds.): Mujer y vestimenta. Aspectos de la identidad femenina en la Antigüedad, pp. 4966. Publicacions de la Univesitat de València. Valencia.

ORTIZ GARCÍA, Jónatan. 2020: Tejidos para la divina muerte. Los sudarios pintados del Egipto romano. Universitat de Barcelona. Edicions. Barcelona.

PERDIGONES, Lorenzo; MUÑOZ, Ángel; PISANO, G. 
1990: "La necrópolis fenicio-púnica de Cádiz. Siglos VI-IV a.C." Studia Punica, 7, pp. 57-62.

PERDIGONES, Lorenzo; TROYA, Ana; MUÑOZ, Ángel. 1987: "Excavaciones de urgencia en un solar de la Avenida Andalucía (Cádiz) en 1985". Anuario Arqueológico de Andalucía. Tomo III, pp. 71-73.

PERDRIZET, Paul. 1921: Les terres cuites grecques d'Égypte de la collection Fouquet. I. Texte. Berger-Levrault. Nancy - París - Estrasburgo.

PERDRIZET, Paul. 1921: Les terres cuites grecques d'Égypte de la collection Fouquet. II. Planches. Berger-Levrault. Nancy - París - Estrasburgo.

PODVIN, Jean-Louis. 2001: "Anubis et Isis sur des lampes à huile romaines. A propos d'une terre cuite du Musée des Antiquités nationales à Saint-Germain-en-Laye". Revue du Louvre et des Musées de France, 4, pp. 33-36.

PODVIN, Jean-Louis. 2003: "La triade Isis - Harpocrate - Anubis sur des lampes africaines". Nouveautés lychnologiques (2003), pp. 207-210.

PODVIN, Jean-Louis. 2005: "Lampes d'Anubis seul”. En L. CHRZANOVSKI (dir.): Lychnological Acts 1. Actes du 1er Congrès international d'études sur le luminaire antique (Nyon-Genève, 29.IX - 4.X.2003), pp. 263-269. Editions Monique Mergoil. Montagnac.

RIHA, Emilie, 1979: Die römischen Fibeln aus Augst und Kaiseraugst. Forschungen in Augst 3.

ROULLET, Anne, 1972: The Egyptian and Egyptianizing monuments of Imperial Rome. Leiden. Brill.

SÁENZ PRECIADO, José Carlos; PRIETO LÓPEZ, Diego. 2015: "La representación de temas orientalizantes en la terra sigillata hispánica", en M.I. Fernández García, P. Ruiz Montes y M. V. Peinado Espinosa (eds.): Terra sigillata hispánica. 50 años de investigaciones, Gorgonzola, Quazar, pp. 455-463. Quasar.
SÁEZ ESPIGLARES, Antonio. 1979: "Hallazgos arqueológicos en Barbate". Boletín del Museo de Cádiz, II, pp. 45-49.

TRAN TAM TINH, Vincent. 1990: "Isis". LIMC, V.1, pp. 761-796; V.2, pp. 501-526.

VERSLUYS, Miguel John. 2002: Aegyptiaca Romana: Nilotic Scenes and the Roman Views of Egypt. Brill. Leiden.

WALTERS, Elizabeth J. 1988: Attic Grave Reliefs that Represent Women in the Dress of Isis. American School of Classical Studies at Athens. Princeton.

WIESE, André B.; PAGE-GASSER, Madeleine. 1997: Ägypten, Augenblicke der Ewigkeit: unbekannte Schätze aus Schweizer Privatbesitz. Philipp von Zabern. Maguncia.

WITT, R. E. 1971: Isis in the Graeco-Roman World. Aspects of Greek and Roman Life. Cornell University Press. Ithaca.

WOLINSKI, Arelene 1986: "Ancient Egyptian ceremonial masks". Discussions in Egyptology, 6, pp. 47-53.

WOLINSKI, Arelene 1987: "Egyptian masks: the priest and his role". Archaeology, 40.1, pp. 2229. 